\title{
Survival Rate and Growth juvenile of African Catfish (Clarias gariepinus) Against the Probiotic Effective Microorganism-4 (EM-4) on the Contain Feed
}

\section{Kelulusan Hidup Dan Pertumbuhan Benih Ikan Lele Dumbo (Clarias gariepinus) Terhadap Pemberian Probiotik Effective Microorganism-4 (EM-4) Pada Pakan}

\author{
Helentina Mariance Manullang* \\ Fakultas Perikanan Universitas Dharmawangsa Medan \\ Jalan K.L. Yos Sudarso No. 224 Glugur Kota Medan 20115 \\ "Email: manullanghelen@gmail.com
}

Diterima 22 Januari 2020 dan Disetujui 31 Maret 2020

\begin{abstract}
Abstrak
Pemanfaatan probiotik disinyalir dapat membantu meningkatkan daya tahan tubuh ikan dan memperbaiki kualitas air, tentunya memperbaiki tingkat kelulusan hidup. Penelitian ini bertujuan untuk mengetahui pengaruh penggunaan probiotik EM-4 (Effective Microorganisme-4) pada pakan terhadap terhadap tebar yang berbeda dalam peningkatan kelulusan hidup dan pertumbuhan ikan lele dumbo. Penelitian ini dilaksanakan dari bulan September sampai bulan Oktober 2019. Rancangan yang digunakan adalah Rancangan Acak Lengkap dengan 4 perlakuan 3 ulangan. Perlakuan berupa jumlah kepadatan penebaran yang berbeda (P1: 50 ekor/48 liter air), (P2 : 65 ekor/48 liter air), (P3 : 80 ekor/48 liter air) dan (P4 : 95 ekor/ 48 liter air). Data dianalisis dengan Analisis Variansi (ANAVA) setelah memenuhi persyaratan, selanjutnya dilakukan uji homogenitas ragam galat dan menggunakan sebaran chi-kuadrat dengan rumus Steel dan Torries (2003). Hasil menunjukkan jumlah kepadatan penebaran yang berbeda berpengaruh terhadap pertumbuhan dan kelulusan hidup benih ikan lele dumbo (Clarias gariepinus). Kepadatan penebaran yang optimal terhadap pertumbuhan dan kelulusan hidup benih ikan lele dumbo kepadatan penebaran 50 ekor/48 liter air, dengan rata-rata kelulusan hidup 90,66 \%, rata-rata pertumbuhan berat mutlak 19,10 gram dan rata-rata pertumbuhan panjang tubuh $9 \mathrm{~cm}$.
\end{abstract}

Kata Kunci: lele dumbo (Clarias gariepinus), probiotik, padat tebar, kelulusan hidup, pertumbuhan

\begin{abstract}
This study aimed to determine the effect of the use of EM-4 probiotics (effective microorganisms-4) in feed on different stockings in increasing the survival rate and growth of African catfish. This research was conducted by the Faculty of Fisheries Laboratory of the Dharmawangsa University Medan from September to October 2019. The design used in this study was a completely randomized design, with 4 treatments 3 replications. The treatment consists of the different amounts of stocking density (P1: 50 fish / 48 liters of water), (P2: 65 fish / 48 liters of water), (P3: 80 fish / 48 liters of water) and (P4: 95 fish / 48 liters of water). The observation result Data is analyzed by variance analysis (ANAVA) after meeting the requirements, Subsequently conducted a variety of error test homogenized and use a chi-squared spread with the formula Steel and Torries (2003). The results showed that the different amounts of stocking density affected the growth and graduation of African catfish (Clarias gariepinus) seeds. The optimal density of stocking on the growth and graduation of live African catfish is the density of $50 \mathrm{fish} / 48$ liters of water, with an average survival rate of $90.66 \%$, average growth of
\end{abstract}


absolute weight of 19.10 grams and average growth length of $9 \mathrm{~cm}$.

Keywords: African catfish, Clarias gariepinus, probiotics, stocking density, survival rate, growth

\section{PENDAHULUAN}

Lele dumbo (Clarias gariepinus) adalah salah satu ikan air tawar yang masuk ke indonesia pada tahun 1985. Ikan lele dumbo merupakan salah satu dari berbagai jenis ikan yang sudah banyak dibudidayakan di Indonesia. Kelebihan ikan lele diantaranya adalah pertumbuhan cepat, pemeliharaan relatif mudah, dapat dipelihara dalam lahan sempit dengan padat tebar yang tinggi dan tahan terhadap lingkungan yang kurang baik, selain itu ikan lele memiliki rasa yang enak dengan kandungan gizi yang tinggi sehingga sangat banyak diminati dikalangan masyarakat (Banjarnahor et al., 2015).

Salah satu yang menjadi permasalahan yang dialami oleh petani yaitu keterbatasan lahan dalam membudidayakan ikan, sehingga produksi ikan yang dihasilkan oleh petani masih belum memenuhi permintaan yang tinggi.Kondisi dengan keterbatasan lahan maka perlu dilakukan pola budidaya secara intensif. Intensifikasi merupakan salah satu alternatif untuk meningkatkan produksi ikan yang dengan carameningkatkan padat penebaran dengan memanfaatkan lahan yang terbatas dan memiliki produktivitas yang tinggi. Salah satu pendorong pengembangan akuakultur adalah pemanfaatan lahan sempit dengan pola manajemen akuakultur yang efektif dan efesien (Mukti et al., 2010).

Intensifikasi budidaya khususnya padat penebaran yang tinggi membawa dampak buruk terhadap pertumbuhan ikan budidaya serta penurunan kualitas lingkungan budidaya. Apabila kepadatan terlalu tinggi akan mengakibatkan kanibalisme yang tinggi dan juga menyebabkan pertumbuhan menjadi lambat sebagai akibat adanya persaingan ruang, oksigen, dan pakan (Murtidjo, 2001).

Pakan merupakan salah satu unsur penting dalam kegiatan budidaya yang menunjang pertumbuhan dan kelangsungan hidup ikan budidaya. Pakan pada kegiatan budidaya umumnya adalah pakan komersial yang menghabiskan sekitar 60$70 \%$ dari total biaya produksi yang dikeluarkan. Hal inilah yang menyebabkan pentingnya pakan sehingga perlu dilakukan penelitian untuk memperbaiki nilai nutrisi pakan yaitu dengan penambahan probiotik (Arief et al., 2014).

Pemberian probiotik dalam akuakultur dapat diberikan melalui pakan maupun air. Dalam probiotik terdapat bakteri yang memiliki cara kerja menghasilkan beberapa enzim yang bermanfaat bagi pencernaan. Beberapa enzim pencernaan dalam pakan seperti amilase, protease, lipase dan selulase. Enzim tersebut yang akan membantu menghidrolisis nutrien pakan (molekul kompleks) seperti karbohidrat, protein dan lemak menjadi molekul yang lebih sederhana akan mempermudah proses pencernaan dan penyerapan dalam saluran pencernaan ikan (Putra, 2010).

Salah satu probiotik yang dikenal di pasaran adalah EM-4.Probiotik EM-4 (Effective Microorganism-4) merupakan salah satu jenis pupuk cair yang mengandung mikroba, terutama bakteri asam laktat dan ragi, dengan mekanisme kerja fermentasi.Pertumbuhan mikroba dalam bahan pakan menyebabkan perubahan yang menguntungkan, seperti perbaikan bahan pakan dari segi mutu baik aspek gizi maupun daya cerna (Rachmawati, 2006).

Berdasarkan hasil penelitian (Banjarnahor et al., 2015) penggunaan EM-4 berpengaruh terhadap pertumbuhan bobot ikan lele dumbo dengan menggunakan EM-4 adalah $6 \mathrm{ml} / \mathrm{kg}$ pakan. Oleh karena itu pemanfaatan probiotik yang 
dicampurkan ke dalam pakan ikan lele dumbo dengan padat tebar berbeda perlu dilakukan.Di dalam hal ini juga untuk memanfaatkan lahan yang terbatas dengan meningkatkan padat tebar dan mendapatkan produktivitas yang tinggi maka perlu dilakukan penelitian tentang penggunaan probiotik EM-4 (effective microorganism-4) pada pakan terhadap padat tebar yang berbeda dalam peningkatan kelulusan hidup dan pertumbuhan benih ikan lele dumbo (Clarias gariepinus).

Tujuan dari penelitian ini adalah mengetahui pengaruh pemberian terhadap kelulusan hidup ikan lele dumbo, mengetahui dosis perlakuan terbaik, mengetahui kualitas air yang optimal selama penelitian. Manfaat dari penelitian ini bagi petani memberikan informasi tentang kepadatan penebaran yang optimal terhadap kelulusan hidup dan pertumbuhan ikan lele dumbo (Clarias gariepinus), serta memberikan informasi penggunaan probiotik EM-4 dalam menunjang budidaya ikan. Bagi pengembangan ilmu pengetahuan dapat dijadikan sebagai referensi untuk penelitian selanjutnya bagi perkembangan ilmu pengetahuan khususnya di dunia sains. Bagi pendidikan menambah wawasan tentang kepadatan penebaran ikan lele yang optimal, serta penggunaan probiotik EM-4 dalam menunjang budidaya ikan.

\section{METODE PENELITIAN}

Waktu dan Tempat

Penelitian ini telah dilaksanakan di Laboratorium Fakultas Perikanan Universitas Dharmawangsa Medan dari bulan September 2019 sampai Oktober 2019.

\section{Alat dan Bahan}

Adapun Alat dan Bahan yang digunakan dalam pelaksanaan penelitian ini yaitu dapat dilihat pada tabel 1 dan 2 berikut ini:

Tabel 1. Alat yang digunakan selama penelitian

\begin{tabular}{lll}
\hline No & Nama Alat & Kegunaan \\
\hline 1 & Akuarium kapasitas 50 liter & Wadah penelitian \\
2 & Aerasi & Menyuplai oksigen \\
3 & Penggaris & Untuk mengukur panjang ikan \\
4 & Timbangan digital & Untung mengukur berat ikan \\
5 & Thermometer & Untuk mengukur suhu \\
6 & pH meter & Untuk mengukur pH air \\
7 & DO meter & Mengukur oksigen terlarut dalam air \\
8 & Ember & Tempat sampel ikan \\
9 & Serokan & Untuk mengambil ikan dari akuarium \\
10 & Baskom & Tempat fermentasi pakan \\
11 & Kamera & Dokumentasi \\
12 & Spluit & Untuk mengukur EM-4 dan air pelarut \\
13 & Alat tulis & Untuk mencatat hasil yang telah \\
\hline
\end{tabular}

Tabel 2. Bahan yang digunakan selama penelitian

\begin{tabular}{lll}
\hline No & Nama Bahan & Kegunaan \\
\hline 1 & Benih ikan lele dumbo ukuran $6 \mathrm{~cm}$ & Sebagai ikan uji \\
2 & Pellet Ff-999 & Sebagai pakan ikan \\
3 & Probiotik EM-4 & Untuk meningkatkan kualitas pakan \\
5 & Air & Sebagai pelarut probiotik EM-4 \\
\hline
\end{tabular}

Rancangan Penelitian

Penelitian ini merupakan penelitian eksperimen. Rancangan yang dilakukan adalah Rancangan Acak Lengkap (RAL) dengan 4 perlakuan dan 3 ulangan. Perlakuan 
yang diterapkan adalah sebagai berikut:

1. Perlakuan $\mathrm{P} 1=(\mathrm{A} 1, \mathrm{~A} 2, \mathrm{~A} 3)$ dengan padat tebar 50 ekor $/ 48$ liter

2. Perlakuan $\mathrm{P} 2=(\mathrm{B} 1, \mathrm{~B} 2, \mathrm{~B} 3)$ dengan padat tebar 65 ekor $/ 48$ liter

3. Perlakuan $\mathrm{P} 3=(\mathrm{C} 1, \mathrm{C} 2, \mathrm{C} 3)$ dengan padat tebar 80 ekor $/ 48$ liter

4. Perlakuan $\mathrm{P} 4=(\mathrm{D} 1, \mathrm{D} 2, \mathrm{D} 3)$ dengan padat tebar 95 ekor $/ 48$ liter

(Keterangan : P1-P4 = Rancangan Perlakuan Penelitian; A1-A3 = Ulangan Penelitian P1; B1-B3 = Ulangan Perlakuan P2; C1-C3 = Ulangan Perlakuan P3; D1-D3 = Ulangan Perlakuan P4)

\section{Prosedur Penelitian}

Persiapan wadah

Wadah yang digunakan dalam penelitian yaitu akuarium dengan ukuran $60 \mathrm{~cm}$ x 40 $\mathrm{cm} 40 \mathrm{~cm}$ sebanyak 12 buah.Akuarium sebelum digunakan terlebih dahulu dibersihkan.

\section{Pengisian air}

Akuarium diisi dengan air bersih dengan menggunakan selang yang dialiri dari bak penampung air.Volume air pada setiap akuarium adalah 48 liter. Masing-masing akuarium diberi label perlakuan, serta diberi aerasi selama pemeliharaan.

\section{Persiapan ikan uji}

Ikan yang digunakan adalah ikan lele dumbo yang diperoleh Mina Sari Medan Senembah. Ukuran panjang ikan yang digunakan rata - rata $6 \mathrm{~cm}$ dan berat rata-rata 1,6 gram sebanyak 870 ekor. Sebelum ikan ditebar terlebih dahulu dilakukan pengukuran panjang dan berat ikan sebagai data awal.

\section{Penebaran ikan uji}

Benih dimasukan ke dalam akuarium dengan kepadatan masing-masing 50 ekor/48 liter, 65 ekor/48 liter, 80 ekor/48 liter, 95 ekor/48 liter air. Sebelum ikan ditebar diaklimatisasi atau diadaptasi pada suhu wadah pemeliharaan.

\section{Persiapan pakan}

Pakan yang ditimbang sebanyak $5 \%$ dari total bobot ikan pada setiap perlakuan. Kemudian disiapkan EM-4 sebanyak $6 \mathrm{ml} / \mathrm{kg}$ pakan, lalu EM-4 dilarutkan dalam air, jumlah air yang digunakan sebanyak $30 \%$ dari total bobot pakan setiap perlakuan. Kemudian pakan dicampur EM-4 yang telah dilarutkan dalam air, lalu pakan difermentasikan di dalam wadah tertutup selama 2 hari.

\section{Pemberian pakan}

Pakan yang diberikan pada ikan lele selama penelitian berupa pelet komersial Ff-999 yang telah di campur dengan EM-4 dan telah difermentasikan selama 2 hari.Pemberian pakan dilakukan 3 kali dalam sehari pada pagi hari, siang dan malam, dengan jumlah pemberian pakan $5 \%$ dari bobot ikan.

\section{Sampling mengetahui berat dan panjang benih ikan}

Benih ikan lele dilakukan pengukuran panjang dan berat setiap satu minggu, dengan mengambil beberapa sampel ikan, serta melakukan pengamatan dengan melakukan pengukuran panjang dan berat ikan, sehingga dapat mengetahui bagaimana perbedaan pertumbuhan dengan padat tebar yang berbeda, dan dapat juga diketahui berapa banyak pakan yang harus diberikan setiap perlakuan. 
Adapun rumus yang digunakan untuk mengetahui kelulusan hidup ikan yang di uji menggunakan rumus Effendie (1979) berikut :

$$
\mathrm{SR}=\frac{\mathrm{Nt}}{\mathrm{No}} \mathrm{x} 100 \%
$$

Keterangan

$\mathrm{SR}=$ Tingkat Kelulusan Hidup

$\mathrm{Nt}$ = Jumlah individu ikan uji yang hidup pada akhir pengamatan

$\mathrm{N} 0=$ Jumlah individu ikan uji yang hidup pada awal pengamatan

\section{Pertumbuhan Berat Mutlak}

Pertambahan berat mutlak dapat dihitung dengan menggunakan rumus Effendie (1979) berikut:

$$
\mathrm{GR}=\frac{W t}{\mathrm{Wo}_{0}}
$$

Keterangan

$\mathrm{GR}=$ Pertumbuhan mutlak (gr/hari);

$\mathrm{Wt}=$ Berat rata-rata pada waktu ke $\mathrm{t}$ (gr);

Wo $=$ Berat rata-rata awal penebaran benih (gr)

\section{HASIL DAN PEMBAHASAN \\ Kelulusan Hidup}

Hasil penelitian menunjukkan bahwa nilai kelulusan hidup (SR) tertinggi terdapat pada P1 yaitu sebesar 90,66 \% dengan padat tebar 50 ekor/48 liter air, sedangkan kelulusan hidup(SR) terendah terdapat pada P4 sebesar 81,04\% dengan padat tebar 95 ekor/48 liter air. Selanjutnya dapat dilihat gambar histogram berikut:

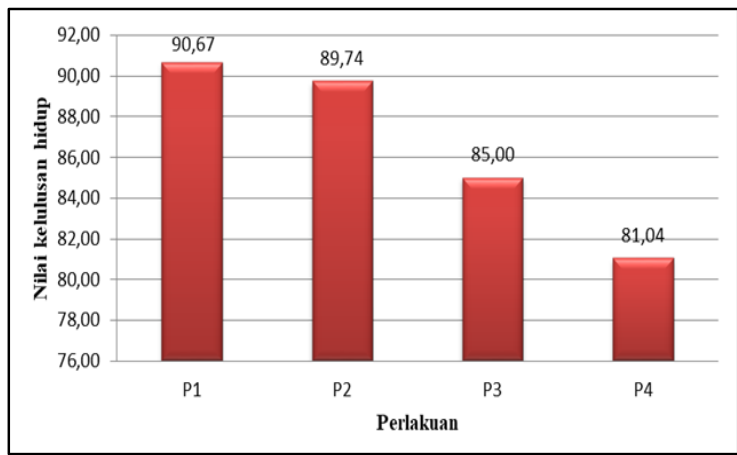

Gambar 1.Nilai Rata-Rata Kelulusan Hidup Benih Lele Dumbo (\%)

Hasil Penelitian menunjukan kelulusan hidup tertinggi terdapat pada P1 kemudian disusul oleh P2, P3 dan nilai yang terendah P4.Nilai kelulusan hidup cenderung menurun sejalan dengan peningkatan padat penebaran benih ikan.Kematian benih ikan yang terjadi setiap pelakuan pada hari kedua diduga akibat stres pada saat pengangkutan benih. Pada P1 memiliki kelulusan hidup tertinggi disebabkan beberapa faktor yaitu ruang gerak yang memadai atau tidak terlalu padat, tidak terjadi perebutan oksigen, kompetisi mendapatkan makanan rendah, dan kadar amonia di dalam wadah pemeliharaan rendah sehingga tingkat kelulusan hidup lebih tinggi dibanding perlakuan lainnya.

Secara deskriptif nilai kelulusan hidup pada penelitian ini lebih tinggi jika dibandingkan dengan nilai kelulusan hidup pada penelitian Waker et al., (2015), yang 
membahas mengenai pengaruh padat tebar tinggi terhadap pertumbuhan dan kelangsungan hidp ikan lele dumbo (Clarias gariepinus) hasil yang didapat nilai tertinggi dicapai pada $\mathrm{P} 1$ sebesar $81,75 \%$ dan nilai terendah pada pada P3 sebesar 75,44 \%. Menurut hasil penelitian Lumbanbatu et al., (2018), yang membahas tentang pertumbuhan dan kelulusan hidup ikan lele dengan padat tebar yang berbeda menggunakan probiotik boster aquaenzyms pada pakan, mendapatkan hasil kelulusan hidup tertinggi sebesar 89,33\% dan hasil terendah sebesar 75,42\%.

Nilai kelulusan hidup pada penelitian ini lebih tinggi jika dibandingkan dengan penelitian atas, diduga karena penambahan probiotik EM-4 mampu memberikan kelulusan hidup yang tinggi.Seperti yang dinyatakan Telaumbanua et al., (2018) bahwa penggunaan probiotik dapat meningkatkan tingkat kelangsungan hidup ikan dan daya tahan tubuh ikan terhadap infeksi patogen serta mengurangi beban lingkungan karena akumulasi limbah di perairan. Pada penelitian Banjarnahor et al., (2015) menjelaskan bahwa penggunaan EM-4 pada pakan ikan memberikan pengaruh nyata terhadap tingkat kelangsungan hidup ikan lele dumbo.

Berdasarkan uji Analisis Variansi didapatkan hasil signifikansi $0,20<0,5$ atau Fhitung $(5,943)>$ Ftabel $(4,07)$ menunjukkan bahwa pengunaan probiotik EM4 pada pakan terhadap padat tebar yang berbeda memberi pengaruh yang berbeda nyata (significant*) $(\mathrm{P}<0,05)$ untuk kelulusan hidup benih ikan lele dumbo (Clarias gariepinus). Maka H0 ditolak dan Ha diterima. Dari uji Beda Nyata Terkecil (LSD) (P1-P2), (P1-P3), (P2-P3), dan (P3-P4) menunjukkan berbeda tidak nyata (ns) karena selisih nilai tengah perlakuannya < LSD $(0,05)$ sedangkan $(\mathrm{P} 1-\mathrm{P} 4)$ dan $(\mathrm{P} 2-\mathrm{P} 4)$ menunjukkan berbeda sangat nyata $\left.{ }^{* *}\right)$ karena selisih nilai tengah perlakuannya $>\operatorname{LSD}(0,01)$.

\section{Pertumbuhan Berat Mutlak}

Berdasarkan uji Analisis variansi didapatkan hasil signifikansi $0,000<0,01$ atau $\mathrm{F}_{\text {hitung }}(28,543)>\mathrm{F}_{\text {tabel }}(7,59)$ menunjukkan bahwa pengunaan probiotik EM-4 pada pakan terhadap padat tebar yang berbeda memberi pengaruh yang berbeda sangat nyata (highlysignificant $\left.{ }^{* *}\right)(\mathrm{P}<0,01)$ untuk pertumbuhan berat mutlak benih ikan lele dumbo (Clarias gariepinus). Maka $\mathrm{H}_{0}$ ditolak dan $\mathrm{H}_{\mathrm{a}}$ diterima. Dari uji Beda Nyata Terkecil (LSD) (P1-P2), (P2-P3), (P3-P4) menunjukkan berbeda nyata $\left(^{*}\right)$ karena selisih nilai tengah perlakuannya $>\mathrm{LSD}_{(0,05)}$ sedangkan $(\mathrm{P} 1-\mathrm{P} 3),(\mathrm{P} 1-\mathrm{P} 4)$ dan $(\mathrm{P} 2-\mathrm{P} 4)$ menunjukkan berbeda sangat nyata $\left.{ }^{* *}\right)$ karena selisih nilai tengah perlakuannya $>\operatorname{LSD}_{(0,01)}$

Dari hasil penelitian menunjukkan bahwa nilai pertumbuhan berat mutlak tertinggi terdapat pada P1 yaitu sebesar 19,10 gr dengan padat tebar 50 ekor/48 liter air, sedangkan nilai pertumbuhan berat mutlak terendah terdapat pada P4 sebesar 10,10 gram dengan padat tebar 95 ekor/48 liter air.

Pada gambar 2 jelas terlihat bahwa nilai rata - rata pertumbuhan berat mutlak tertinggi terdapat pada P1 $(19,10)$ kemudian disusul oleh P2 $(15,97)$, P3 $(13,43)$ dan nilai yang terendah P4 $(10,10)$. Pertumbuhan berat benih ikan lele dumbo (Clarias gariepinus) cenderung menurun sejalan dengan peningkatan padat penebaran benih ikan. Tingginya pertumbuhan berat pada P1 diduga karena ikan memanfaatkan pakan secara optimal dan parameter kualitas air sesuai dengan kebutuhan sehingga ikan tidak banyak mengeluarkan energi untuk beraktivitas dalam memperebutkan ruang, namun energi yang didapatkan dari makanan dijadikan untuk pertumbuhan. Sesuai pendapat Lumbanbatu et al., (2018) menyatakan tinggginya pertumbuhan berat ikan dikarenakan ruang gerak dan padat tebar sesuai dengan kondisi ikan sehinggga tingkat persaingan terhadap perebutan makanan dan pemanfaatan pakan dapat terjadi dengan baik. 


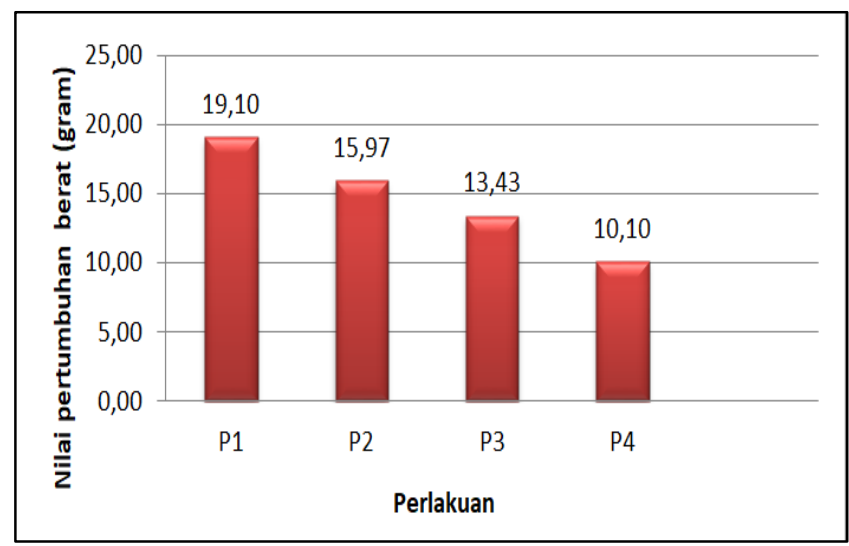

Gambar 2. Diagram Nilai Rata - Rata Pertumbuhan Berat Mutlak

Rendahnya pertumbuhan berat pada P4 diduga karena akibat dari padat tebar yang tinggi sehingga terjadi kompetisi dalam memperebutkan ruang gerak dan mendapatkan makanan, sehingga ikan akan mengeluarkan energi yang lebih tinggi untuk aktivitas tersebut yang menyebabkan energi untuk pertumbuhan lebih sedikit dibanding padat penebaran yang lebih rendah. Hal ini sesuai dengan pendapat Handajani \& Hastuti (2002) menyatakan bahwa semakin tinggi kepadatan ikan maka akan mempengaruhi tingkah laku dan fisiologi ikan terhadap ruang gerak yang menyebabkan pertumbuhan, pemanfaatan makanan dan kelulushidupan mengalami penurunan. Abidin (2009) Menyatakan bahwa, stres yang muncul akibat dari padat penebaran yang semakin tinggi meningkatkan energi pemeliharaan, hal tersebut akan mengurangi energi yang seharusnya digunakan untuk pertumbuhan.

Secara deskriptif nilai pertumbuhan berat mutlak pada penelitian ini lebih baik jika dibandingkan dengan hasil penelitian Lumbanbatu et al., (2018) yang membahas tentang pertumbuhan dan kelulusan hidup ikan lele dengan padat tebar yang berbeda menggunakan probiotik boster aquaenzyms pada pakan, mendapatkan hasil pertumbuhan berat mutlak tertinggi sebesar 16,16 gram, yang dipelihara selama 35 hari dengan kepadatan 50 ekor /72 liter air.

Nilai pertumbuhan berat mutlak pada penelitian ini lebih tinggi jika dibandingkan dengan hasil penelitian Telaumbanua (2018), diduga karena dengan menggunakan probiotik EM-4 (Effective Microorganism-4) mampu mempercepat pertumbuhan berat ikan lele dumbo. Sesuai dengan penelitian Khotimah et al., (2016) menjelaskan bahwa pemberian probiotik pada media pemeliharaan tidak hanya memperbaiki kualitas air akan tetapi juga dapat meningkatkan pertumbuhan ikan. Menurut Banjarnahor et al., (2015) menyatakan bahwa pemberian probiotik EM-4 berpengaruh nyata terhadap pertumbuhan bobot ikan lele, dengan menggunakan probiotik EM-4 $6 \mathrm{ml} / \mathrm{kg}$ pakan. Hal ini didukung oleh Arief et al., (2014) yang mengemukakan bahwa mikroorganisme probiotik dapat membantu meningkatkan kualitas pakan melalui serangkaian mekanisme enzimatis dan mempercepat laju pertumbuhan yang ditandai dengan penambahan berat tubuh ikan lele.

\section{KESIMPULAN}

Dari penelitian ini dapat disimpulkan bahwa Penggunaan probiotik EM-4 pada pakan terhadap pada tebar yang berbeda memberikan pengaruh sangat nyata (highly significant $\left.{ }^{* *}\right)(\mathrm{P}<0,01)$ terhadap pertumbuhan berat benih ikan lele dumbo (Clarias gariepinus) perlakuan tertinggi terdapat pada P1 sebesar 19,10 gr dan perlakuan terendah terdapat pada $\mathrm{P} 4$ sebesar 10,10 gr.

Penggunaan probiotik EM-4 pada pakan terhadap pada tebar yang berbeda 
memberikan pengaruh sangat nyata (highly significant**) $(\mathrm{P}<0,01)$ terhadap pertumbuhan panjang benih ikan lele dumbo (Clarias gariepinus) perlakuan tertinggi terdapat pada $\mathrm{P} 1$ sebesar $9 \mathrm{~cm}$ diikuti dengan $\mathrm{P} 2$ sebesar 7,90 cm, P3 sebesar $6,80 \mathrm{~cm}$ dan perlakuan terendah terdapat pada $\mathrm{P} 4$ sebesar $5,4 \mathrm{~cm}$.

Penggunaan probiotik EM-4 pada pakan terhadap pada tebar yang berbeda memberikan pengaruh sangat nyata (highly significant**) $(\mathrm{P}<0,01)$ terhadap nilai rasio konversi pakan benih ikan lele dumbo (Clarias gariepinus) perlakuan terendah terdapat pada P1 sebesar 0,5305, diikuti dengan P2 sebesar 0,637, P3 sebesar 0,722 kemudian perlakuan tertinggi terdapat pada $\mathrm{P} 4$ sebesar 0,975 .

\section{DAFTAR PUSTAKA}

Abidin, Z. 2009. Kinerja Produksi Benih Gurame (Osphronemus gouramy) Lac. Ukuran 8 cm dengan Padat Penebaran 3, 6 dan 9 Ekor/L pada Sistem Resirkulasi. Bogor: Institut Pertanian Bogor.

Arief, M., Nur F., Sri S. 2014. Pengaruh Pemberian Probiotik Berbeda Pada Pakan Komersial Terhadap Pertumbuhan Dan Efesiensi Pakan Ikan Lele Sangkuriang (Clarias sp.). Jurnal Ilmiah Perikanan dan kelautan, Volume 6(1): 49-53.

Banjarnahor, D.M., Usman S., Leidonald R. 2015. Pengaruh Pemberian Probiotik EM-4 (Effective Microorganism-4) Pada Pakan Terhadap Pertumbuhan dan Kelangsungan Hidup Benih Ikan Lele Sangkuriang (Clarias gariepinus). Jurnal Aquacoastmarine. Volume 4(2): 1-10.

Dimenta, R. H., Agustina, R., Machrizal, R. (2020). Kualitas Sungai Bilah Berdasarkan Biodiversitas Fitoplankton. Volume 11(2), 24-33.

Effendi, MI. 1979. Metoda Biologi Perikanan. Bogor: Yayasan Dwi Sri.

Handajani, H., Hastuti, S.D. 2002. Budidaya Perairan. Malang: UMM Press.

Khotimah, K., Harmalia E.D., Sari R. 2016. Pemberian Probiotik Pada Media Pemeliharaan Benih IkanPatin (Pangasius hypophthalmus) Dalam Akuarium. Jurnal Akuakultur Rawa Indonesia, Volume 4(2) : 152-158.

Lumbanbatu, PA, Mulyadi., Pamukas NA. 2018. Influence of EM4 Probiotic In Artificial Feed With Different Doses To Growth and Life of Red Tilapia (Oreochromis niloticus) In Brackish Water. Jurnal Online Mahasiswa Fakultas Perikanan dan Ilmu Kelautan Universitas Riau. Volume 5(2): 1-11.

Mukti, A.T., Satyantini W.H, Arief M. 2010. Penuntun Pratikum Bioteknologi Akuakultur. Fakultas Perikanan dan Kelautan Universitas Airlanggga. 36 Hal.

Murtijdo, B.A. 2001. Beberapa Metode Pembenihan Air Tawar. Kanisius, Yogjakarta.

Putra, A.N. 2010. Kajian Probiotik, Prebiotik dan Sinbiotik Untuk MeningkatkanKinerja Pertumbuhan Ikan Nila (Oreochromis niloticus). Bogor: Program Pasca Sarjana InstitutPertanian Bogor. 
Rachmawati, F.N., Untung S., Bambang, H. 2006. Penggunaan EM-4 dalam Pakan Buatan Meningkatkan Keefesienan Pakan dan Pertumbuhan Ikan Nila Gift (Oreochromis sp.). Jurnal Agrolan. Volume 13(3) : 270-274.

Telaumbanua, N.T., Rusliadi., Pamukas N.A. 2018. Pertumbuhan Dan Kelulushidupan Ikan Lele Dumbo (Clarias gariepinus) Dengan Padat Tebar Berbeda Menggunakan Probiotik Boster Aquaenzyms Pada Pakan. Jurnal Online Mahasiswa Fakultas Perikanan dan Ilmu Kelautan Universitas Riau, Volume 6(5): 1-13.

Waker, M.B.J., Djayus Y., Usman S. 2015. Pengaruh Padat Tebar Tinggi Terhadap Pertumbuhan Dan Kelangsungan Hidup Ikan Lele Dumbo (Clarias gariepinus). Jurnal Aquacoastmarine. Volume 3(4): 1-8. 